\title{
KADAR HEMOGLOBIN, HITUNG JUMLAH ERITROSIT DAN NILAI HEMATOKRIT PADA PEKERJA PARKIRAN BASEMENT DI KOTA MAKASSAR
}

\author{
Hemoglobin Level, calculate erythrocyte amount and hematocrit value \\ in basement parking workers in makassar city \\ Ulandhary $^{1}$, Nurlia Naim², Zulfikar Ali Hasan ${ }^{3}$, Zulfian Armah ${ }^{4}$ \\ ${ }^{1}$ Prodi Teknologi Laboratorium Medis Poltekkes Kemenkes Makassar \\ 2,3,4 Jurusan Analis Kesehatan Poltekkes Kemenkes Makassar
}

Koresponden: lan.alkaline.dh@gmail.com / 082353645095

\begin{abstract}
Basement is usually used as a parking area, but some basement developments pay less attention to the adequacy of the ventilation. As a result, exhaust gases from vehicles can increase indoor air pollution. Carbon monoxide gas produced from incomplete combustion of motorized vehicles has a stronger affinity for hemoglobin than oxygen. The body will compensate for the lack of oxygen by producing more red blood cells so that the hematocrit increases. The purpose of this study was to determine the hemoglobin level $(\mathrm{Hb})$, calculate the number of erythrocytes and hematocrit values $(\mathrm{Ht})$ in basement parking workers in the city of Makassar. This study is a laboratory observation with a descriptive approach that uses primary data. The sampling technique was done by purposive sampling as many as 15 samples. Results of hemoglobin levels decreased by $26.67 \%$ with the lowest levels were $12.9 \mathrm{mg} / \mathrm{dL}$, normal hemoglobin levels as much as $53.33 \%$ and hemoglobin levels increased by $20 \%$ with the highest levels of $16.7 \mathrm{mg} / \mathrm{dL}$. Calculate the number of normal erythrocytes as much as $93.33 \%$ and count the number of erythrocytes increased by $6.67 \%$ with the highest number of erythrocytes 5.97 million $/ \mu l,$. The hematocrit value decreased by $26.67 \%$ with the lowest value of $37.6 \%$ and the normal hematocrit value of $73.33 \%$. From the results of the study it can be concluded that the hemoglobin level, the number of erythrocytes, and the hematocrit value in basement parking workers in Makassar City are still within normal limits.
\end{abstract}

Keywords : Basement, Erythrocyte, Hematocrit, Hemoglobin

\begin{abstract}
ABSTRAK
Basement biasanya digunakan sebagai area parkir, akan tetapi beberapa pembangunan basement kurang memperhatikan kecukupan ventilasinya. Akibatnya gas buang dari kendaraan dapat meningkatkan polusi udara dalam ruang. Gas karbon monoksida yang dihasilkan dari pembakaran tidak sempurna kendaraan bermotor memiliki afinitas lebih kuat terhadap hemoglobin dibandingkan oksigen. Tubuh akan mengimbangi kekurangan oksigen dengan memproduksi sel darah merah lebih banyak sehingga hematokrit meningkat. Tujuan penelitian ini untuk mengetahui kadar hemoglobin $(\mathrm{Hb})$, hitung jumlah eritrosit dan nilai hematokrit $(\mathrm{Ht})$ pada pekerja parkiran basement di kota Makassar. Penelitian ini bersifat observasi laboratorik dengan pendekatan deskriptif yang menggunakan data primer. Teknik pengambilan sampel dilakukan secara purposive sampling sebanyak 15 sampel. Hasil kadar hemoglobin
\end{abstract}


menurun sebanyak 26,67\% dengan kadar terendah adalah 12,9 mg/dL, kadar hemoglobin normal sebanyak 53,33\% dan kadar hemoglobin meningkat sebanyak 20\% dengan kadar tertinggi $16,7 \mathrm{mg} / \mathrm{dL}$. Hitung jumlah eritrosit normal sebanyak 93,33\% dan hitung jumlah eritrosit meningkat sebanyak $6,67 \%$ dengan jumlah eritrosit tertinggi 5,97 juta/ $\mu 1$,. Nilai hematokrit menurun sebanyak 26,67\% dengan nilai terendah 37,6\% dan nilai hematokrit normal sebanyak 73,33\%. Dari hasil penelitian dapat ditarik kesimpulan bahwa kadar hemoglobin, hitung jumlah eritrosit, dan nilai hematokrit pada pekerja parkiran basement di Kota Makassar masih dalam batas normal.

Kata kunci : Basement, Eritrosit, Hematokrit, Hemoglobin

\section{PENDAHULUAN}

Pembangunan basement sering kali kurang memperhitungkan kecukupan ventilasinya sehingga nilai rasio perubahan udara atau air change ratio $(\mathrm{ACH})$ berada dibawah normal sehingga berakibat terakumulasinya polutan. Secara paparan, pencemaran udara dalam ruang jauh lebih besar dibanding pencemaran luar ruang. Oleh karenanya WHO menyatakan bahwa pencemaran udara dalam ruang seribu kali lebih dapat mencapai paru dibandingkan dengan pencemaran udara luar ruang. (Huboyo et al. 2016).

Hemoglobin $(\mathrm{Hb})$ adalah komponen utama dari sel darah merah (eritrosit), merupakan protein terkonjugasi yang berfungsi untuk transportasi oksigen (O2) dan karbon dioksida (CO2). Salah satu hemoglobin abnormal diantaranya, hemoglobin yang berikatan dengan karbon monoksida (karboksihemoglobin). Meningkatnya jumlah dari setiap jenis hemoglobin abnormal disebabkan penyerapan zat atau obat yang berbahaya (Kiswari, 2014).

Oksigen yang kalah bersaing dengan karbon monoksida, menyebabkan jaringan kekurangan suplai oksigen yang dapat menyebabkan terjadinya hipoksia jaringan. Hipoksia merangsang pembentukan sel darah merah (eritropoiesis) untuk memenuhi kebutuhan oksigen dalam darah, sehingga memproduksi sel darah merah lebih banyak.
Dalam sebuah penelitian terhadap hasil pemeriksaan morfologi eritrosit dan hematokrit pada pekerja parkiran basement salah satu mall di Kota Makassar dari 10 sampel yang diperiksa semua sampel mempunyai nilai hematokrit yang meningkat dengan nilai hematokrit terendah $45 \%$ dan hematokrit tertinggi yaitu 50\% (Amran, 2016).

\section{METODE}

Jenis penelitian ini merupakan penelitian observasi laboratorik, yaitu dimaksudkan untuk mengetahui kadar hemoglobin $(\mathrm{Hb})$, hitung jumlah eritrosit dan nilai hematokrit $(\mathrm{Ht})$ pada pekerja parkiran basement di Kota Makassar. Teknik pengambilan sampel yang digunakan adalah purposive sampling. Populasi penelitian adalah pekerja parkiran basement di Kota Makassar sebanyak 50 orang. Sampel yang digunakan adalah pekerja parkiran basement yang memenuhi kriteria inklusi penelitian dengan besar sampel dalam penelitian sebanyak 15 sampel. Dengan kriteria sampel inklusi yaitu laki-laki, pekerja parkiran basement yang telah bekerja minimal 1 tahun, bekerja 8-10 jam/hari dan bersedia berpartisipasi. Adapun kriteria eksklusi yaitu perempuan, penderita penyakit ginjal dan sumsum tulang.

Waktu penelitian dilaksanakan pada bulan Maret 2019. Penelitian dilaksanakan di Balai Besar Kesehatan Paru Masyarakat Makassar (BBKPM). 
Pengumpulan Data

Pengumpulan data meliputi instrumen penelitian yaitu informed concent / persetujuan setelah penjelasan, kuesioner, dan Hematology Analyzer Mindray BC-5300.

Prosedur kerja dalam penelitian ini memiliki tiga tahapan yaitu pra analitik, analitik dan pasca analitik. Tahap pra analitik meliputi alat pemeriksaan yaitu spuit, tourniquet (pembendung), tabung EDTA tutup ungu, cool-box dan Mindray BC-5300. AdapunBahan Pemeriksaan yaitu darah vena, kapas alkohol 70\%, dan kapas kering.

Tahap analitik meliputi cara pengambilan sampel. Dipasang tourniquet pada lengan atas, mintalah pasien mengepal dan membuka tangannya berkali-kali agar vena jelas terlihat, bersihkan tempat yang akan ditusuk dengan alkohol 70\% dan biarkan sampai mengering. Tusuklah kulit dengan spuit sampai darah masuk kedalam ujung spuit. Lepaskan atau renggangkan tourniquet dan perlahanlahanlah tarik penghisap spuit sampai jumlah sampel yang diinginkan. Taruhlah kapas di atas lokasi penusukan dan tarik keluar jarum spuit. Minta pasien agar menekan bekas tusukan selama beberapa menit dengan kapas kering. Pindahkan sampel ke dalam tabung EDTA tutup ungu dengan mengalirkan darah melalui dinding tabung. Tutup tabung dan segeralah homogenkan darah dengan antikoagulan EDTA selama 60 detik atau lebih. Ambillah darah untuk pemeriksaan langsung dari tabung tersebut, bila pemeriksaan tak dapat dilakukan segera, simpan di dalam cool-box untuk menjaga stabilitas sampel dan biarkan mendapat suhu kamar lebih dahulu sebelum darah tersebut diperiksa (Gandasoebrata, 2013).

Selanjutnya cara pemeriksaan kadar hemoglobin $(\mathrm{Hb})$, hitung jumlah eritrosit dan nilai hematokrit (Ht). Nyalakan komputer (CPU dan monitor), klik 2 kali ikon/shortcut aplikasi Mindray BC-5300 pada desktop layar monitor komputer Setelah masuk di menu utama Mindray BC-5300, login dengan mengisi user name dan password, kemudian klik OK. Nyalakan alat Mindray BC-5300 dengan cara menekan tombol ON pada power di samping bagian belakang alat. Tekan YES apabila muncul note "skip fluidics initialization". Sebelum membaca sampel pasien, terlebih dahulu membaca kosong alat dengan cara tekan aspirate tanpa sampel untuk membuat semua hasil parameter menjadi netral atau " 0 " biasanya dibaca kosong sampai $2 \mathrm{x}$. Setelah semua parameter netral atau " 0 " maka dilanjutkan dengan membaca kontrol (kalau ada) kemudian sampel pasien, hasil pemeriksaan pasien keluar dalam bentuk print out.

Tahapan terakhir yaitu pasca analitik dengan interpretasi hasil:

Hemoglobin: $12,0-16,0 \mathrm{~g} / \mathrm{dL}$

Hitung Jumlah Erirosit: 4,0 - 5,5 juta/mL

Hematokrit: $37-54 \%$

Analisa Data

Data yang diperoleh dari hasil pemeriksaan kadar hemoglobin $(\mathrm{Hb})$, hitung jumlah eritrosit dan nilai hematokrit $(\mathrm{Ht})$ dianalisis secara deskriptif dalam bentuk persen, yang disajikan dalam bentuk tabel dengan rumus :

$$
\%=\mathrm{t} / \mathrm{n} \times 100 \%
$$

Keterangan :

$\mathrm{t}=$ hasil yang meningkat, normal, dan menurun

$\mathrm{n}=$ jumlah sampel

\section{HASIL}

Berdasarkan hasil penelitian analisis kadar hemoglobin, hitung jumlah eritrosit, dan nilai hematokrit pada pekerja parkiran basement di Kota 
Makassar, dari 15 sampel pemeriksaaan didapatkan hasil kadar hemoglobin menurun 4 sampel $(26,67 \%)$, normal 8 sampel $(53,33 \%)$ dan meningkat 3 sampel (20\%). Hasil hitung Jumlah eritrosit normal sebanyak 14 sampel $(93,33 \%)$ dan meningkat 1 sampel $(6,67 \%)$. Adapun nilai hematokrit menurun 4 sampel $(26,67 \%)$ dan normal 11 sampel $(73,33 \%)$.

\section{PEMBAHASAN}

Penelitian yang dilakukan bersifat observasi laboratorik dengan menganalisis kadar hemoglobin, hitung jumlah eritrosit, dan nilai hematokrit pada pekerja parkiran basement di Kota Makassar sebanyak 15 sampel dengan teknik pengambilan sampel secara purposive sampling. Dalam penelitian ini digunakan kuesioner untuk mempermudah pemilihan sampel pekerja parkiran basement. Kriteria inklusi yang digunakan adalah laki-laki, telah bekerja minimal 1 tahun, bekerja 8 - $10 \mathrm{jam} / \mathrm{hari}$ dan bersedia berpartisipasi. Pengambilan sampel dengan melakukan pungsi vena, kemudian sampel darah diperiksa menggunakan Hematology Analyzer Mindray BC-5300.

Berdasarkan hasil penelitian didapatkan kadar hemoglobin meningkat sebanyak 3 sampel dengan kadar hemoglobin tertinggi $16,7 \mathrm{mg} / \mathrm{dL}$, kadar hemoglobin menurun sebanyak 4 sampel dengan kadar terendah adalah 12,9 $\mathrm{mg} / \mathrm{dL}$ dan kadar hemoglobin normal sebanyak 8 sampel dengan kadar hemoglobin 14,2-15,8 mg/dL.

Beberapa faktor yang dapat mempengaruhi hasil pemeriksaan diantaranya yaitu, jenis kelamin, posisi pasien sebelum dan selama pengumpulan darah, stres, umur dan merokok

Jenis kelamin merupakan faktor yang mempengaruhi konsentrasi sejumlah komponen darah. Sebagian besar perbedaan yang jelas hanya setelah kematangan seksual dan ditunjukkan dalam nilai normal yang bebeda untuk laki-laki dan perempuan. Misalnya, kadar hemoglobin, hitung jumlah eritrosit, dan nilai hematokrit lebih tinggi untuk laki-laki daripada perempuan (Kiswari, 2014).

Posisi tubuh sebelum dan selama pengumpulan darah dapat mempengaruhi komposisi spesimen. Dari posisi berbaring ke posisi duduk atau posisi berdiri tegak menyebabkan pengaliran cairan darah ke jaringan, dan penurunan volume plasma pada orang dewasa, akibatnya konsentrasi komponen darah meningkat (Kiswari, 2014).

Kualitas tidur yang kurang dapat menjadi salah satu faktor pemicu stres. Berdasarkan kuesioner yang dibagikan, beberapa pekerja parkiran basement yang dijadikan sampel tidak cukup tidur di malam hari atau memiliki kebiasaan begadang.

Berdasarkan hasil penelitian didapatkan hitung jumlah eritrosit meningkat sebanyak 1 sampel dengan jumlah eritrosit 5,97 juta/ $\mu 1$, dan jumlah eritrosit normal sebanyak 14 sampel dengan jumlah eritrosit 4,45 - 5,46 $\mathrm{juta} / \mu \mathrm{l}$.

Dari hasil penelitian yang dilakukan oleh Nurlia Naim (2013) terhadap studi penetapan kadar hemoglobin dan jumlah eritrosit pada juru parkir di Kota Makassar dari 20 sampel didapatkan kadar hemoglobin dalam batas normal $100 \%$ dengan kadar hemoglobin terendah 13,0 $\mathrm{mg} / \mathrm{dL}$ dan kadar hemoglobin tertinggi $16,6 \mathrm{mg} / \mathrm{dL}$. Adapun jumlah eritrosit normal $80 \%$, jumlah eritrosit meningkat $20 \%$ dengan jumlah eritrosit terendah yaitu 4,20 juta/ $\mu 1$ dan jumlah eritrosit tertinggi yaitu $6,69 \mathrm{juta} / \mu \mathrm{l}$.

Nilai untuk beberapa komponen darah bervariasi tergantung pada umur. 
Eritrosit dan leukosit biasanya lebih tinggi pada bayi baru lahir dibandingkan pada orang dewasa (Kiswari, 2014).

Faktor lain yang dapat mempengaruhi jumlah eritrosit yaitu merokok. Tidak bisa dipungkiri kebiasaan merokok di kalangan masyarakat sudah menjadi gaya hidup. Akan tetapi sejumlah komponen darah dipengaruhi oleh kebiasaan merokok. Besarnya efek ini tergantung pada jumlah rokok yang diisap. Merokok kronis sering menyebabkan menurunnya fungsi paru serta meningkatkan jumlah eritrosit dan kadar hemoglobin (Kiswari, 2014).

Berdasarkan hasil penelitian didapatkan nilai hematokrit menurun sebanyak 4 sampel dengan nilai terendah $37,6 \%$ dan nilai hematokrit normal sebanyak 11 sampel dengan nilai 41,4$49,3 \%$.

Dari hasil penelitian sebelumya oleh Prawansa Amran (2017) terhadap hasil pemeriksaan morfologi eritrosit dan hematokrit pada pekerja parkiran basement MTC Makassar dari 10 sampel didapatkan nilai hematokrit yang tinggi atau meningkat melebihi nilai normal dengan nilai hematokrit terendah yaitu $45 \%$ dan nilai hematokrit tertinggi 50\%.

Jumlah eritrosit dan kadar hemoglobin tidak selalu meningkat atau menurun bersamaan. Hal ini tentu dipengaruhi keadaan fisiologi tubuh dari pola hidup dan pola makan.

\section{KESIMPULAN}

Dari hasil penelitian dapat ditarik kesimpulan bahwa kadar hemoglobin, hitung jumlah eritrosit, dan nilai hematokrit pada pekerja parkiran basement di Kota Makassar masih dalam batas normal.

\section{SARAN}

Disarankan kepada pekerja parkiran basement untuk menggunakan alat pelindung diri (APD) khususnya masker saat bekerja, memperhatikan kesehatan dalam pola makan, istirahat, olahraga dan disarankan untuk melakukan pemeriksaan kesehatan secara berkala atau medical check up. Kepada peneliti selanjutnya disarankan untuk memperbanyak jumlah sampel dan melakukan pengambilan sampel dari basement lainnya di Kota Makassar.

\section{UCAPAN TERIMAKASIH}

Kami mengucapkan banyak terimakasih kepada semua pihak yang telah berjasa dalam penelitian ini terutama kepada Kepala Balai Besar Laboratorium Kesehatan Makassar dan Jurusan Analis Kesehatan

\section{DAFTAR PUSTAKA}

Amran, P. 2016. Studi Gambaran Morfologi Eritrosit dan Hematokrit Pada Pekerja Parkiran Basement MTC (Makassar Trade Center) Kota Makassar. Jurnal Media Analis Kesehatan Vol. VII, Makassar: Poltekkes Kementerian Kesehatan RI. Harrianto, R. 2010. Buku Ajar Kesehatan Kerja. Jakarta : EGC.

Gandasoebrata, R. 2013. Penuntun laboratorium Klinik. cetakan keenambelas, Jakarta : Dian Rakyat

Huboyo, H.S. Istirokhatun, T. Sutrisno, E. 2016. Kualitas Udara Dalam Ruang Di Daerah Parkir Basement Dan Parkir Upperground (Studi Kasus Di Supermarket Semarang. Jurnal Presipitasi: Media Komunikasi dan Pengembangan Teknik Lingkungan, Available from https://ejournal.undip.ac.id/index. $\mathrm{php} / \mathrm{presipitasi/article/view/11118}$ (Diakses 29 November 2018).

Kiswari, R. 2014. Hematologi dan Transfusi. Jakarta : Erlangga. 
Naim, N. 2013. studi penetapan kadar hemoglobin dan jumlah eritrosit pada juru parkir di Kota Makassar.
Jurnal Media Analis Kesehatan Vol. IV, Makassar : Poltekkes Kementerian Kesehatan RI. 
Tabel 1

Hasil Pemeriksaan Kadar Hemoglobin, Hitung Jumlah Eritrosit dan Nilai Hematokrit Pada Pekerja Parkiran Basement di Kota Makassar

\begin{tabular}{|c|c|c|c|c|c|c|}
\hline $\begin{array}{c}\text { Kode } \\
\text { Sampel }\end{array}$ & $\begin{array}{c}\text { Kadar } \\
\text { Hemoglobin } \\
(\mathrm{g} / \mathrm{dL})\end{array}$ & Ket & $\begin{array}{l}\text { Jumlah } \\
\text { Eritrosit } \\
(\mathrm{juta} / \mu \mathrm{l})\end{array}$ & Ket & $\begin{array}{c}\text { Nilai } \\
\text { Hematokrit } \\
(\%)\end{array}$ & $\begin{array}{c}\mathrm{Ke} \\
\mathrm{t}\end{array}$ \\
\hline Sampel A & 16,7 & $\uparrow \uparrow$ & 5,46 & - & 47,9 & - \\
\hline Sampel B & 15,8 & - & 5,31 & - & 46,1 & - \\
\hline Sampel C & 16,4 & $\uparrow$ & 5,44 & - & 47,2 & - \\
\hline Sampel D & 15,5 & - & 4,96 & - & 43,8 & - \\
\hline Sampel E & 12,9 & $\downarrow$ & 5,97 & $\uparrow$ & 37,6 & $\downarrow$ \\
\hline Sampel F & 15,1 & - & 4,95 & - & 43,8 & - \\
\hline Sampel G & 13,2 & $\downarrow$ & 4,45 & - & 38,0 & $\downarrow$ \\
\hline Sampel H & 13,4 & $\downarrow$ & 4,61 & - & 39,8 & $\downarrow$ \\
\hline Sampel I & 14,2 & - & 5,30 & - & 41,4 & - \\
\hline Sampel J & 14,7 & - & 5,02 & - & 44,1 & - \\
\hline Sampel K & 15,8 & - & 5,17 & - & 46,3 & - \\
\hline Sampel L & 13,6 & $\downarrow$ & 4,47 & - & 38,8 & $\downarrow$ \\
\hline Sampel M & 16,3 & $\uparrow$ & 5,23 & - & 46,8 & - \\
\hline Sampel N & 15,4 & - & 5,15 & - & 45,7 & - \\
\hline Sampel O & 14,8 & - & 4,94 & - & 49,3 & - \\
\hline \multicolumn{7}{|c|}{ Sumber : Data Primer 2019} \\
\hline \multicolumn{7}{|c|}{ Keterangan : } \\
\hline$\downarrow \quad:$ & \multicolumn{6}{|c|}{ Menurun } \\
\hline - & \multicolumn{6}{|c|}{ : Normal } \\
\hline$\uparrow$ & \multicolumn{6}{|c|}{ Meningkat } \\
\hline
\end{tabular}

